\title{
Dictadura, Democracia y Justicia Transicional en Brasil: Trayectoria y Legados del Supremo Tribunal Federal*
}

\section{Andrés del Río}

Universidade Federal Fluminense (UFF), Angra dos Reis, RJ, Brasil. E-mail: andres.delrio@gmail.com

Excluem-se de qualquer apreciação judicial todos os atos praticados de acordo com este Ato Institucional e seus Atos Complementares, bem como os respectivos efeitos. (Acto Institucional no 6, artículo 4. Febrero, 1969)

Se é verdade que cada povo resolve os seus problemas

históricos de acordo com a sua cultura, com os seus sentimentos, com a sua índole, também com a sua história, o Brasil fez uma opção pelo caminho da concórdia. E digo, se eu pudesse concordar com a afirmação de que certos homens são monstros, eu diria que os monstros não perdoam, só o homem perdoa, só uma sociedade superior, qualificada pela consciência do mais elevado sentimento de humanidade é capaz de perdoar, porque só uma sociedade que, por ter grandeza é maior do que os seus inimigos, é capaz de sobreviver. (Cezar Peluso, ministro del Supremo Tribunal Federal) ${ }^{1}$

\footnotetext{
* Este artículo fue desarrollado durante la beca post-doctoral en el Instituto Nacional de Ciencia y Tecnología en Políticas Públicas, Estrategias y Desarrollo en el Instituto de Estudios Sociales y Políticos (IESP) de la Universidad del Estado de Río de Janeiro (UERJ) y en el Instituto de Economía (IE) de la Universidad Federal de Río de Janeiro (UFRJ), con el apoyo del Consejo Nacional de Desarrollo Científico y Tecnológico (CNPq). Agradezco especialmente Eli Diniz y Renato Boschi, además de los colegas del Instituto. Remarco el apoyo y las contribuciones de Charles Pessanha. Finalmente, agradezco a Breno Bringel y a los evaluadores anónimos de DADOS - Revista de Ciências Sociais por las oportunas sugerencias.
}

DADOS - Revista de Ciências Sociais, Rio de Janeiro, vol. 57, no4, 2014, pp. 1169 a 1201. 
Com base no direito internacional e em sua jurisprudência

constante, a Corte Interamericana concluiu que as disposições da Lei de Anistia que impedem a investigação e sanção de graves violações de direitos humanos são incompatíveis com a Convenção Americana e carecem de efeitos jurídicos, razão pela qual não podem continuar representando um obstáculo para a investigação dos fatos do caso, nem para a identificação e a punição dos responsáveis ${ }^{2}$. (Corte Interamericana de Derechos Humanos)

\section{UNA APROXIMACIÓN}

$\mathrm{D}$ iversos países de América del Sur se encuentran en un intenso proceso de consolidación democrática y fortalecimiento de sus estados de derecho a partir de la búsqueda de memoria, verdad y justicia por lo ocurrido en el contexto de sus últimos regímenes autoritarios. En este sentido, cada país lidia con el pasado violento a su propia manera y a la velocidad que le es propia. En el caso brasileño, el reciente establecimiento de la Comisión de la Verdad es un indicio más del avance en la búsqueda de la verdad con horizonte en la justicia ${ }^{3}$. Promover la lucha contra las políticas del olvido y los legados institucionales autoritarios es un desafío constante para la sociedad. La justicia transicional (JT) lidia en el presente con estos legados autoritarios, pero, además, el Poder Judicial, en general, y el Supremo Tribunal Federal (STF), en particular, conviven con estos legados vivos establecidos desde la ruptura institucional de 1964. El análisis de ese legado es imprenscindible para comprender el estado actual de la justicia transicional en Brasil. Como indica Abrão (2011:121): “...algo marcante do caso brasileiro é, sem dúvida, o não desenvolvimento da dimensão da regularização da justiça e o restabelecimento da igualdade perante a lei, entendida como restabelecimento substancial do Estado de direito, com a devida proteção judicial às vítimas e a consecução da obrigação do Estado em investigar e punir crimes, sobretudo as violações graves aos direitos humanos". De esta forma, al negar el pasado violento, se niega su legado en el presente. Y, así, se impide a la democracia avanzar y se erosiona su futuro.

En este sentido, se destacan los legados autoritarios del Supremo Tribunal en democracia. En particular, este trabajo trata de un estudio 
cualitativo e interdisciplinario, basado tanto en discursos, documentos y legislación oficial como en la jurisprudencia seleccionada del Alto Tribunal. También fueron utilizadas fuentes secundarias para ubicar contextualmente cada uno de los eventos, especialmente el escenario político. El periodo temporal seleccionado es amplio y comienza en 1964, de modo a captar toda la prolongada etapa dictatorial brasileña. A partir de 1985, se observa la trayectoria democrática al puntualizar ciertos legados autoritarios del STF hasta el presente. En definitiva, el objetivo principal del presente artículo es contribuir al debate actual sobre la justicia transicional en Brasil.

\section{CAMBIOS, TRANSFORMACIONES Y COALICIONES}

Este artículo observa, a través de la complejidad de la historia, el proceso de desarrollo institucional del Alto Tribunal. En este sentido, siguiendo a Thelen y Streeck (2005:18), se pueden realizar y observar importantes cambios conjuntamente con una fuerte continuidad institucional. Existe la posibilidad de cambiar significados y funciones en instituciones estables. Las teorías contemporáneas sobre desarrollo institucional ubican, en general, al cambio como una ruptura abrupta. Pero, además de hablar de ruptura y discontinuidad, se podría comenzar a observar también las transformaciones que resultan de la acumulación de un cambio gradual e incremental (Pierson, 2008). Como sugiere Thelen (2004), no se debe generar una profunda división entre estabilidad y cambio institucional. A veces los cambios institucionales son abruptos, pero otras, no. A veces, muestran un patrón de cambio incremental a través de realineamientos políticos y de renegociación. El desafío es reflexionar sobre cómo una cierta institución persiste y cambia a través del tiempo, en particular el Supremo Tribunal Federal en el contexto del régimen militar y de su retorno democrático.

La construcción institucional involucra la realización de coaliciones y, por lo tanto, moviliza a varios sectores sociales y actores políticos en apoyo de una configuración institucional determinada. Los actores tratan de interpretar o reorientar las instituciones para alcanzar ventajas para el logro de sus objetivos, intereses o para evadir las reglas que chocan con sus intereses. Por lo tanto, al observar los cambios que se producen en las coaliciones se pone de manifiesto cómo las instituciones se apoyan en ellas. Así, centrarse en la renegociación política es crucial para comprender cómo las instituciones se configuran, qué realizan y cómo cambian a través del tiempo (Thelen, 2004:31-33). Es por 
ello que, en el transcurso del presente texto, se analiza el escenario político en el cual se desarrolla institucionalmente el Supremo Tribunal Federal.

A diferencia del resto de golpes de Estado producidos en la región, el caso brasileño muestra particularidades en las formas y modos de los cambios institucionales originados en esta etapa dictatorial. A partir de 1964, se observan transformaciones graduales y cambios abruptos simultáneos en su arquitectura institucional. Se examinan aquellos cambios producidos tanto en su estructura como en sus capacidades, de manera formal o informal. Los medios formales serían la legislación específica y los informales se enmarcarían en el campo político sin el establecimiento de ninguna legislación específica. Estas alteraciones pueden apuntar a la estructura o a las capacidades del Alto Tribunal. En el primer caso, se trataron de cambios en el número de miembros del tribunal como así también de los jueces propiamente dichos. En el segundo caso, apuntan a alterar las atribuciones como, por ejemplo, al limitar o aumentar la jurisdicción del tribunal, entre otros (del Río, 2010). De forma didáctica:

Tabla 1

Formas y Objetos de Alteración en el Alto Tribunal

\begin{tabular}{l|l|l}
\hline Medios-Objetos & \multicolumn{1}{|c}{ Estructura } & \multicolumn{1}{|c}{ Capacidades } \\
\hline \multirow{3}{*}{ Formales } & $\begin{array}{l}\text { - Cantidad de integrantes por } \\
\text { Ley o Constitución } \\
\text { - Juicio político a ministros }\end{array}$ & $\begin{array}{l}\text { - Alterar atribuciones o juris- } \\
\text { dicción por ley o Constitución } \\
\text { - Creación de tribunales espe- } \\
\text { ciales } \\
\text { - Garantías constitucionales }\end{array}$ \\
\hline \multirow{3}{*}{ Informales } & $\begin{array}{l}\text { - Renuncias políticas } \\
- \text { No completar vacantes } \\
\text { - Demora en la confirmación } \\
\text { de ministros. }\end{array}$ & $\begin{array}{l}\text { - Demora o no ejecución de } \\
\text { sentencias. }\end{array}$ \\
\hline
\end{tabular}

Fuente: Elaboración propia. Según nuestra base de datos.

Mientras los politólogos suelen observar la estructura de la Corte, los estudiosos del derecho constitucional analizan sus capacidades. En este sentido, observar las transformaciones tanto en las estructuras como en las capacidades es necesario para entender con mayor profundidad las características del caso en estudio. Si se compara la Corte Suprema a un coche de carreras, los cambios en la estructura alterarían el conductor y los cambios en las capacidades alterarían el motor. Como 
indica Montaigne, por diferentes caminos se puede llegar a un mismo lugar. Pero el análisis del cómo se llega es importante. Al examinar este complejo período histórico y sus consecuencias presentes, se ofrece un análisis más profundo de los cambios institucionales durante el régimen cívico-militar y los legados autoritarios en la democracia.

\section{EL GOLPE DE 1964 Y LOS CAMBIOS INSTITUCIONALES}

El 9 de abril, la junta militar compuesta por el general del Ejército Arthur da Costa e Silva, el teniente brigadier Francisco de Assis Correia de Melo y el vicealmirante Augusto Hamann Rademaker Grünewald dictó el Acto Institucional no 1 (AI). En su primer artículo declaraba: "São mantidas a Constituição de 1946 e as Constituições estaduais e respectivas emendas, com as modificações constantes dêste Ato". A pesar de seguir en vigor, la Constitución de 1946 estaba derrotada y sufrió, en el tiempo, constantes ataques. El AIno 1 otorgó al gobierno militar la facultad de revocar mandatos legislativos, suspender derechos políticos por 10 años, poner en disponibilidad o jubilar compulsivamente a cualquier persona que hubiera atentado contra la Seguridad Nacional ${ }^{4}$. Tan solo en los primeros meses del régimen arbitrario, se estima que se detuvo a 50 mil personas (Mezarobba, 2004:8). Además, el AI no 1 determinó las elecciones indirectas para presidente de la República para el 11 de abril. El mandato fue limitado hasta el 31 de enero de $1966^{5}$. El artículo 7 declaraba que: “Ficam suspensas, por seis meses, as garantias constitucionais ou legais de vitaliciedade e estabilidade" y, en su inciso 4ㅇ que afectaba particularmente al STF, declaraba que: "O controle jurisdicional desses atos limitar-se-á ao exame de formalidades extrínsecas, vedada a apreciação dos fatos que o motivaram, bem como da sua conveniência ou oportunidade". Sin embargo, este Acto Institucional no fue aislado ni tampoco el único.

En su presidencia, Castelo Branco intentó mantener el respeto por el STF. Así, lo dejó en claro al visitar al Alto Tribunal a días de asumir el cargo. En el mismo sentido, lo entendieron los ministros de ese período (Vale, 1976:31) ${ }^{6}$. Pero la revolución era mayor que Castelo Branco y la línea dura fue aumentando su presión sobre la presidencia y el Alto Tribunal. La revolución tenía en su génesis la contradicción del estado de derecho y de facto. Sin embargo, no duró mucho tiempo esta ambigüedad. A partir de ciertas decisiones del Alto Tribunal, se comenzó a pensar alternativas para reencauzar esta rama de gobierno. Para intentar apaciguar los ánimos de la línea dura que se exasperaba por las de- 
cisiones del Alto Tribunal ${ }^{7}$, el 27 de octubre de 1965, se dictó el AI no 2, que afectaba particularmente al STF: se amplió el número de ministros del Alto Tribunal a 16 (Court Packing Brasileño); se suspendieron las garantías constitucionales de vitalidad, inamovilidad y de estabilidad; y se declaró en su artículo 19 que:

Ficam excluídos da apreciação judicial: I - os atos praticados pelo Comando Supremo da Revolução e pelo Governo federal, com fundamento no Ato Institucional de 9 de abril de 1964, no presente Ato Institucional e nos atos complementares deste; II - as resoluções das Assembléias Legislativas e Câmara de Vereadores que hajam cassado mandatos eletivos ou declarado o impedimento de Governadores, Deputados, Prefeitos ou Vereadores, a partir de 31 de março de 1964, até a promulgação deste Ato.

Asimismo, se afectaron otras áreas ${ }^{8}$. De esta forma, con el aumento del tamaño del tribunal, se designaron cinco ministros y todos asumieron sus cargos el 25 de noviembre del mismo año. Los ministros designados fueron: Adalício Coelho Nogueira, José Eduardo do Prado Kelly, Oswaldo Trigueiro de Albuquerque Mello, Aliomar de Andrade Baleeiro y Carlos Medeiros Silva. A pesar de los cambios en la estructura del Alto Tribunal, el aumento del número de miembros y las nuevas designaciones no causaron el efecto esperado por los militares. En consecuencia, éstos salieron de los cuarteles y se encontraban en guerra declarada contra el STF.

La Constitución de 1946 vio su labor terminada con el dictado del AI no 4, del 7 de diciembre de 1966, que convocaba al Congreso Nacional para la discusión, votación y promulgación del proyecto de Constitución presentado por el Presidente de la Republica. Según el gobierno militar: "somente uma nova Constituição poderá assegurar a continuidade da obra revolucionária”. Además, la maraña jurídica ya se había descontrolado y la nueva Constitución apuntó a la normalización en este sentido. En noviembre de 1965, la enmienda constitucional no 16 alteró profundamente al Poder Judicial ${ }^{9}$. En ésta se institucionalizó la Justicia Federal, ya enunciada en el AI n.2. También, permitió al STF juzgar las leyes o actos normativos federales mediante la representación del Procurador General de la República. En este sentido, el control de la constitucionalidad se fortaleció. Al lado del control difuso, se instauró el control concentrado (Dias Corrêa, 1987:16). Como sugiere Vilhena Vieira: 
O problema surge na forma pela qual se configurou a legitimidade ativa, ou seja, a capacidade de provocar a jurisdição do Supremo. Atribuído com exclusividade ao Procurador Geral da Republica, demissível ad nutum pelo Presidente, tornou-se um instrumento de pouco valor no controle dos atos inconstitucionais produzidos pelo Executivo ou de interesse deste. OSupremo Tribunal Federal só chegaria a apreciar uma questão de inconstitucionalidade, por via de ação direta, se esse alto funcionário, de confiança do Presidente, assim o quisesse. Surgiu dessa maneira um método de controle concentrado não apenas no sentido técnico-jurídico, mas principalmente político (1994:79).

\section{LA CONSTITUCIÓN DE 1967}

El nuevo texto constitucional entró en vigor conjuntamente con la asunción a la presidencia de Costa e Silva, el 15 de marzo de 1967. El flamante texto fundamental intentó institucionalizar y legalizar el régimen militar de forma más armoniosa, al dejar atrás la mutilación jurídica de los primeros años del gobierno. Sin embargo, cuanto más institucionalizada estaba la revolución más se alejaba de la "democracia". En palabras de Ribeiro Bastos: "Na verdade poderíamos dizer que, a despeito do texto constitucional, afirmar a existência de três poderes, no fundo existia um só, que era o Executivo, visto que a situação reinante tomava por demais mesquinhas as competências tanto do Legislativo quanto do Judiciário" (1999:157). Puesto que la Seguridad Nacional era su principal objetivo, las garantías constitucionales fueron profundamente afectadas, principalmente las libertades individua$\operatorname{les}^{10}$. Se estableció el habeas corpus y el mandado de segurança (en español, recurso de amparo), pero el primero no siempre tuvo efectividad cuando se trataba de crímenes contra la Seguridad Nacional. Los decretos ley jugaron un papel clave como instrumento de gobierno. La Constitución de 1967 convivió con los actos institucionales y otros instrumentos legales que surgieron en el transcurso del tiempo y que la fueron erosionando constantemente.

Por un lado, el país vivía una situación económica favorable. Por el otro, la oposición política, manifestaciones sociales (particularmente de trabajadores y estudiantes) y actos de violencia se multiplicaban. El 28 de marzo de 1968, murió el estudiante Edson Luís de Lima Souto en un conflicto con la Policía Militar en Río de Janeiro. Un mes después, se prohibió realizar elecciones en 68 municipios al ser considerados áreas de Seguridad Nacional. A fines de junio, 100 mil personas se manifes- 
taron en contra del régimen militar. En octubre del mismo año, 1240 estudiantes fueron presos durante el Congreso de la UNE en Ibiúna. En el mismo mes, se creó el Consejo Superior de Censura. La cúpula militar percibió que a pesar de las medidas realizadas para reencauzar el orden, éstas no tuvieron el efecto esperado, y se hacían necesarias medidas de mayor profundidad.

En ese contexto, el 13 de diciembre de 1968, se agudizó el modelo autoritario al decretarse el AI no 5 . Dictado por el presidente Arthur da Costa e Silva, el Acto Institucional n.5 dio amplios poderes para reprimir a los opositores: se cerró el Congreso Nacional (medida reglamentada por el Acto Complementar no 38), se revocaron mandatos electivos, se suspendieron por diez años los derechos políticos de cualquier ciudadano, se intervinieron Estados y Municipios, se confiscaron bienes por enriquecimiento ilícito y se suspendió el habeas corpus para crímenes políticos contra la Seguridad Nacional y el orden económico y social. En palabras transmitidas por televisión, el entonces presidente declaraba sobre este AI-5: "Salvamos o nosso programa de governo e salvamos a democracia, voltando às origens do poder revolucionário"11. A partir del AI-5, el régimen autoritario aumentó la represión y utilizó la detención, la tortura y el asesinato contra los enemigos o aquellos considerados como tales. En este sentido, en enero de 1969, 43 diputados fueron presos. En julio, se creó la Operación Bandeirantes, centro de represión en São Paulo. Y, en septiembre, se aprobó la nueva ley de Seguridad Nacional, que incluía la pena de muerte. Como indica Gaspari: "Desde 1964, a máquina de repressão exigia liberdade de ação. Com o AI-5, ela a teve e foi à caça" (2002a:351). Y cuanta más libertad obtuvo la maquinaria de represión, menor fue el status del Supremo Tribunal Federal en la política brasileña.

El Acto Institucional no 6 del primero de febrero de 1969 tuvo, una vez más, al Supremo Tribunal Federal como objetivo. En primer lugar, se redujo a once el número de miembros del Alto Tribunal. Como consecuencia de ello, jubilaron compulsivamente a los ministros Evandro Lins e Silva, Hermes Lima y Vitor Nunes Leal. Todos ellos habían tenido una participación activa en la defensa de la Constitución y representaron la razón en el desorden. En secuencia, el ministro Gonçalves de Oliveira renunció al cargo en solidaridad a los ministros apartados forzosamente. Además, se retiró el ministro Lafayette de Andrada. En todos estos casos de alejamiento compulsivo, los ministros no fueron sujetos a un proceso de juicio político o a un proceso formal de remo- 
ción, lo que acentuó los problemas de legitimidad institucional. Se destaca que todos los ministros apartados habían sido designados en democracia. Así, el Supremo Tribunal se renovó casi en su totalidad, entre los designados durante el período democrático, solamente el juez Gallotti se mantuvo en su cargo. Los militares destituyeron aquellos que incomodaban o no interpretaban los fines revolucionarios. En fin, a través de un proceso gradual, se purificó la Corte de aquellos ministros que estorbaban al gobierno usurpador.

También, con este AI se modificó y alteró la competencia del STF, se incrementó la del Superior Tribunal Militar y se ratificaron las enmiendas constitucionales hechas por Actos Complementarios posteriores al AI n no 5 . Según el artículo 4: "Excluem-se de qualquer apreciação judicial todos os atos praticados de acordo com este Ato Institucional e seus Atos Complementares, bem como os respectivos efeitos". El STF se estaba alejando de las funciones que lo caracterizaban. Así, se consiguió huir del control jurisdiccional y de la apreciación de justicia aunque lejos quedó la legitimidad institucional. Sin duda, contradictorios fueron los motivos de tal AI, ya que en sus argumentos declaraba que: “...Considerando haver o Governo, que ainda detém o poder constituinte, admitido, por conveniência da própria Justiça, a necessidade de modificar a composição e de alterar a competência do Supremo Tribunal Federal, visando a fortalecer sua posição de Corte eminentemente constitucional e, reduzindo-lhes os encargos, facilitar o exercício de suas atribuições". De esta manera, el STF tuvo nuevo status institucional, de rol menor, y se renovó en su composición. Como sugiere Vale: "Desde então, sobretudo com a edição dos Atos ns. 5 e 6, cessaram os conflitos, e o Poder Executivo-Revolucionário passou a ter no Supremo um órgão administrativamente saudável, tecnicamente ágil, sobretudo com a reforma que se pretende implantar, mas politicamente morto" (1976:166). En la misma línea se apoya Vilhena Vieira (1994:80) cuando argumenta que, al reducirse en su competencia y cambiar los ministros, el STF no ofreció más resistencia. En fin, desde el AI n.5 hasta octubre de 1978, se decretaron 12 actos institucionales, 59 actos complementarios y 8 enmiendas constitucionales que alteraron sensiblemente la arquitectura institucional del Brasil. Y sensiblemente, la del Supremo Tribunal Federal.

La junta militar integrada por tres militares, Aurélio de Lira Tavares, Augusto Rademaker, y Márcio Melo, se encargó de la administración del país hasta el 30 de octubre de 1969 en un proceso de por sí contro- 
vertido $^{12}$. Antes de su alejamiento, el 17 de octubre de 1969, la junta decretó la enmienda constitucional n.1. Esta dejó en claro la concentración de poder que obtuvo el Ejecutivo al declarar en sus motivos que: "Considerando que, decretado o recesso parlamentar, o Poder Executivo Federal fica autorizado a legislar sobre todas as matérias, conforme

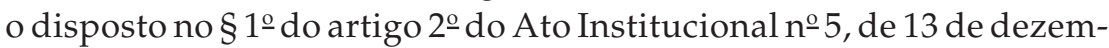
bro de 1968". La enmienda fue extensa en cuanto a las modificaciones que introdujo en la Constitución de 1967. No son pocos los autores que admiten esta enmienda como una Constitución nueva. El AI-5, conjuntamente con la enmienda n.1, amplificó la concentración del poder en el Ejecutivo, así como el unitarismo, y consolidó la arquitectura jurídica legal del régimen militar. A pesar de su autoritarismo descollante, no se modificaron totalmente algunas formas liberales de organización de gobierno (continuaron el Legislativo y el Judicial) ni se aniquilaron completamente los derechos de los ciudadanos, aunque estos fueron restringidos a su punto máximo ${ }^{13}$. Con relación a estos derechos, Barroso (2009:218) sugiere que la Constitución se tornó en una mistificación, un instrumento de dominación ideológica, repleta de promesas que no fueron honradas. Como indica el jurista: "nela se buscava não o caminho, mas o desvio; não a verdade, mas o disfarce". Después de cinco años del golpe militar, el gobierno usurpador alteró de forma profunda las capacidades y estructura del Alto Tribunal. Pero este proceso se presentó de forma gradual y constante. Un rasgo particular del caso brasileño.

A fines de 1969, con Médici al mando del Poder Ejecutivo, la dualidad se instaló temporariamente. Por un lado, el desarrollo económico del país pasaba por un momento notable, siendo denominado el milagro económico brasileño. Este suceso fue importante en el proceso de legitimación del régimen. Por otro lado, simultáneamente, el proceso político aumentaba su represión e incrementaba la tensión social. Como indica Gaspari: “O milagre econômico foi simultâneo à repressão e à luta armada. Ambos reais, co-existiam negando-se" (2002b:18). Así, entre los gobierno de Costa e Silva y Medici, la represión llegó a su máxima expresión en la lucha armada. En breves pero claras palabras Soares indica que:

(...) dados confirmam que houve uma concentração da repressão política em 1964, e depois, nos anos de 1969 a 1973. Que essa repressão foi distribuída por todos os setores da vida nacional, incluindo militares, civis e aparelhos do próprio Estado. No entanto, no que toca à questão dos desaparecidos, dos mortos e dos abusos, a concentração se dá no se- 
gundo momento. Mais do que isso, queremos chamar a atenção para o fato de que o que mudou nessa segunda fase foi o alvo da repressão, envolvendo setores da elite social e cultural do país, o aprimoramento dos métodos, a institucionalização e a organização do sistema repressivo (...)(1994:29).

En este sentido, existieron en este período más de 300 desaparecidos, 25.000 prisioneros políticos, 10.000 exiliados y más de 7.378 personas juzgadas por tribunales militares por crímenes políticos (Pereira, 2003:28).

\section{EL PROCESO DE DISTENSIÓN Y APERTURA}

Con el gobierno de Geisel, iniciado en 1974, se intentó buscar un proceso de normalización. Pero la crisis económica alteró los planes. El régimen militar comenzaba a perder el apoyo de las clases altas y medias que lo sustentaban. En 1974, el régimen conoció la derrota electoral que fue manipulada a través del derecho. En 1977, la enmienda constitucional n.7 aumentó la competencia del STF (Dias Corrêa, 1987:17) ${ }^{14}$. Sin embargo, las reacciones del Congreso, la sociedad civil y del propio judicial mostraron que este refuerzo en el control sirvieron para bloquear el proceso de transición democrática y la autonomía de los jueces (Koerner, 2010:17). Era una ampliación de las capacidades del STF pero con una limitación inherente de sus efectos. Además, se creó el Consejo Nacional de Magistratura con la finalidad de controlar y disciplinar a los jueces, con jurisdicción nacional e integrado por siete ministros del STF de un total de once miembros.

El proceso de apertura presentó varias aristas, no obstante, la cuestión militar fue predominante. A pesar de las divergencias internas en la coalición sobre el funcionamiento del sistema represivo, existió la preocupación de preservar la corporación militar. Esto generó problemas para la apertura política. De esta manera, el proceso fue "lento, gradual y seguro" con fuerte control del régimen. En junio de 1978, se dio de baja el AI-5. En octubre del mismo año, se dictó la enmienda constitucional no 11 que permitió la vuelta de las garantías parlamentarias y la reorganización del sistema de partidos. Pero esto no significó la normalización general. En marzo de 1979, asumió la presidencia Figueiredo.

El 22 de agosto de 1979, se aprobó la Ley de Amnistía. En sus inicios, se exigió una amnistía "amplia, general e irrestricta". Sin embargo, ter- 
minó derrotada por el Congreso Nacional donde se aceptó una ley "restricta" apoyada por el régimen dictatorial. Esta ley era restricta para aquellos involucrados en crímenes políticos. Con el transcurso del tiempo, surgieron varias evidencias de que muchas muertes fueron producto de la acción estatal. En este sentido, como indica Abrão:

(...) cresceu a pressão social pelas investigações dos delitos, o que levou o Judiciário - ressalte-se: controlado pelo regime - a sistematicamente ampliar interpretativamente o espectro de abrangência da lei, passando a considerar "conexos aos políticos" os crimes dos agentes de Estado e, ainda, a aplicar a lei até para crimes ocorridos pós-1979, fora da validade temporal da lei (como para os responsáveis pelo caso Riocentro em 1980), sob o manto do princípio da "pacificação nacional" (2011:123).

De este modo, la amnistía se convirtió en una amnistía bilateral (de doble mano), que beneficiaba de forma amplia, general e irrestricta a los integrantes del régimen autoritario. La ley alcanzada fue un proceso controlado por el régimen autoritario que le otorgó un sentido de acuerdo político-social para cooptar una legitimidad que en la realidad era parcial. Esta supuesta legitimidad se fortaleció con el pasar del tiempo a partir de la legalidad que le concedió el Supremo Tribunal Federal en la democracia, especialmente con la interpretación de la ADPF 153 del 2010 ${ }^{15}$. Se coincide con Mezarobba (2004:12) sobre que el controlado proceso de apertura y transición: "se desarrolló con vistas a evitar que lo que hoy hemos convenido en denominar mecanismos de justicia transicional pudiesen ser adoptados al inicio de la gestión civil".

Por un lado, se presentaba un proceso de atenuación gradual de los instrumentos autoritarios del régimen, en el que el gobierno mantenía el monopolio de la iniciativa y del control sobre las reglas del juego. Por el otro, el país enfrentaba una grave crisis por la deuda externa y, al mismo tiempo, en el plano internacional, la ideología neoliberal se tornaba hegemónica. Simultáneamente, se extinguió el bipartidismo, se produjo una reformulación partidaria y se abrió la posibilidad a nuevos partidos. La campaña popular por el restablecimiento de las elecciones directas para presidente fue destacada. Finalmente, en la arena del gobierno, o sea en el colegio de electores, se ganó el pulso al elegir a Tancredo Neves como presidente de la Republica y Sarney como vice. En relación con la transición y la actuación del STF, Vilhena Vieira: 
O Supremo colaborou para a transição no ritmo estabelecido pela agenda do Planalto. Em diversos episódios onde se buscou o Supremo, tiveram os litigantes suas pretensões frustradas por um tribunal submisso à vontade dos militares. A questão das eleições diretas é significativa para compreender a afinidade entre o Executivo e o Supremo Tribunal Federal. (...) O Supremo Tribunal Federal colaborou assim, na medida de suas competências, para o processo de sucessão do Presidente Figueiredo ficasse limitado ao Colégio Eleitoral, como queriam os Militares (1994:81-82).

\section{DEMOCRACIA, DERECHOS HUMANOS Y LEGADOS AUTORITARIOS}

El retorno a la democracia fue menos abrupto debido a la prolongada, lenta y gradual transición. El proceso de reconstrucción y reforma institucional dio un paso importante con la promulgación de la nueva Constitución de 1988. A pesar del fortalecimiento constitucional, el legado institucional del régimen autoritario se extendió durante la vuelta democrática. Y este se convirtió en un desafío para la democracia.

El Supremo Tribunal Federal fue alterado en sus capacidades a través de la restitución y el aumento de sus potestades constitucionales. Estas atribuciones fortalecidas le otorgaron un importante rol institucional en el proceso de consolidación del nuevo orden democrático. A pesar de estos cambios en las capacidades, su estructura no se alteró. Y este se convirtió en un hecho, por lo menos, conflictivo. Con el cambio del régimen, ninguno de los ministros del Supremo Tribunal Federal fue apartado o removido. Por un lado, se mantuvo el mismo tamaño del STF: once ministros. Por el otro, el cambio de régimen no significó la alteración de sus integrantes. Es decir, miembros designados en momentos no democráticos continuaron en momentos democráticos. Algo similar ocurrió con los ministros, aunque con variaciones ${ }^{16}$. Esta característica particular del Supremo Tribunal Federal (y del Poder Judicial /brasileño) puede ser interpretada de las más diversas formas: coordinación y acuerdo entre las elites político - militares en la selección, manutención constante del status quo, tipo de negociación en la selección, perfil de los jueces seleccionados, entre otros. Sin embargo, fue a través de esta particularidad de la continuidad que el régimen autoritario encontró un resguardo institucional, una especie de póliza de seguro institucional en la democracia. La estructura inalterada del Supremo fue determinante en el perfil jurisprudencial que fortaleció el rasgo de continuidad, de legado. De especial interés es el leading case ADI $n^{0} 2^{17}$, 
propuesta en 1989 y decidida por el STF en 1992. En esta, la mayoría de los ministros acompañó el voto del magistrado Paulo Brossard que indicó que la disposición constitucional sobre Acciones Directas de Inconstitucionalidad no daba a la Corte Suprema el poder de juzgar, en ADIN, la compatibilidad de las leyes preconstitucionales con la Constitución de 1988. Con ella, se definió el papel y la responsabilidad del STF en la vida política del país de aquel momento. El ministro Sepúlveda Pertence, voto vencido en la ADI no 2, observó: "Tenho a ousadia de dissentir, por força de uma firme convicção, de que recusar a via da ação direta de inconstitucionalidade ao expurgo das leis velhas incompatíveis com a nova ordem constitucional seria demitir-se, o Supremo Tribunal Federal, de uma missão e de uma responsabilidade que são suas. Intransferivelmente suas" (Andrade, 2009) ${ }^{18}$. El Supremo, que en ese momento estaba integrado por los ministros que provenían del régimen anterior, estableció la jurisprudencia que consolidó la continuidad, además de constituirse en un límite jurídico para la sociedad. La decisión desincentivó jurídicamente las presentaciones que pretendían revisar la legislación preconstitucional, como la ley de Amnistía (Andrade, 2008:209). En 1999, se promulgó la Ley 9882/99 que reglamentó la Argüição de Descumprimento de Direito Fundamental (ADPF) prevista en el artículo 102, $§ 1$ de la Constitución Nacional de 1988. Ésta se creó para suplantar a las ADIns y habilitó al Supremo Tribunal a revisar la legislación preconstitucional ${ }^{19}$. En el 2010, el STF estableció la validez de la ley de Amnistía a través de la ADPF 153.

En esta línea, se creó un legado institucional que afectó el proceso de consolidación democrático y perjudicó la búsqueda de verdad y justicia. Como indica Abrão (2011: 125): "A ausência de um processo de depuração do Poder Judiciário pós-ditadura permitiu que ali se mantivesse viva uma mentalidade elitista e autoritária...". En este sentido, según Koerner (2009:196), la Ley de Amnistía: "serviu de apoio para a permanência dos quadros do regime autoritário nas instituições estatais". Se destaca que estos legados pueden ser enfrentados por medio de reformas y valores democráticos. Por un lado, las designaciones de ministros para el Alto Tribunal se produjeron principalmente por sucesión natural, sin remociones o juicios políticos ${ }^{20}$. Se privilegiaron los legados y las continuidades por sobre las reformas. Y la reforma de las instituciones públicas es una tarea central para la transformación del entramado público que fue parte del régimen autoritario. Estas reformas institucionales contribuyen a los procesos de justicia transicional (Morales, 2011:81). En tanto que, por otro lado, los valores democráti- 
cos y las políticas de memoria precisan de constante fomento, para que puedan, de manera efectiva, penetrar en las instituciones fuertemente cooptadas por la represión, como fue el Poder Judicial (Torelly, 2010a:121). En este proceso, la justicia transicional puede cooperar fuertemente en la renovación y reconstrucción institucional del Poder Judicial y viceversa (Ndulo et al., 2009:265).

Simultáneamente, en este proceso democrático, la justicia transicional (JT) emerge como respuesta concreta a las violaciones sistemáticas a los derechos humanos durante el último régimen autoritario. En palabras de Genro e Abrão (2010:23): “Seu objetivo é o reconhecimento das vítimas e a promoção de possibilidades de reconciliação e consolidação democrática". La justicia transicional tiene cuatro dimensiones primordiales: la reparación a las víctimas, la búsqueda de la verdad y la construcción de la memoria, la reforma de las instituciones del Estado y el restablecimiento de la igualdad de los individuos frente a la ley. Según el International Center for Transitional Justice (ICTJ): "nenhuma medida única é tão eficaz isoladamente quanto combinada com as outras" (Olsen 2009:166). Brasil tuvo y tiene diferentes niveles de implementación en cada una de estas dimensiones y muchas han sido tardías con relación a otros países de América Latina. Y es a partir de la justicia transicional que se vigorizó la búsqueda de la memoria, verdad y justicia. En contraposición, como se expondrá a continuación, el Supremo Tribunal quedó lejos del rol institucional diseñado por la nueva Constitución para la consolidación del Estado de derecho brasileño. De este modo, la dimensión de reparación se convirtió en el eje central en el que se basaron la mayor parte de las políticas de reconciliación brasileñas. Pero se trató de una reparación sin punición.

De a poco, diversas iniciativas fueron derrumbando las limitaciones impuestas por los legados institucionales autoritarios, los desencuentros políticos y la omnipresente Ley de Amnistía de 1979. En un primer momento, el presidente Fernando Henrique Cardoso firmó la Ley n.9.140/1995, conocida como Ley de los Desaparecidos, que creó la Comissão Especial de Reconhecimento dos Mortos e Desaparecidos Políticos. Con la aprobación de la ley, se admitió por primera vez en Brasil la responsabilidad objetiva del Estado por la actuación ilícita de sus agentes de seguridad (136 personas desaparecidas por razones políticas), sin necesidad de sentencia (BRASIL, 2007:18). Sin embargo, los familiares de las víctimas y sus aliados criticaron los procedimientos y el alcance de esta ley. En ella se negaba tanto la revisión de la Ley de Amnistía 
como la desclasificación de documentación vital y sensible para los interesados. Estos sectores, entre otros, la consideraron como promotora de políticas de olvido y de impunidad (MacDowell Santos, 2007:37)

En un segundo momento, en noviembre de 2002 se dictó la Ley n.10.559, que regulaba el artículo 8 de las disposiciones constitucionales transitorias ${ }^{21}$. En la ley se trató el régimen del amnistiado político y la reparación económica de carácter indemnizatorio. Además, se estableció la Comisión de Amnistía en el Ministerio de Justicia ${ }^{22}$. La ley logró ampliar nuevamente el proceso de ajuste de cuentas, gracias a la posibilidad de que el Estado reparase económicamente a experseguidos políticos, lo que la Ley no 6.683 no había conseguido. De este modo, a partir de la nueva legislación federal (Ley no 9.140 de 1995 y Ley no 10.559 de 2002), nuevos significados comenzaron a construirse. Como indica Mezarobba: "De su carácter inicial de conciliación pragmática, se observa que la amnistía vio evolucionar su significado hacia el reconocimiento de la responsabilidad del Estado en graves violaciones de derechos humanos, y después hacia la reparación económica de las pérdidas sufridas por experseguidos políticos" (2004:16).

A pesar de estas mejoras, el Supremo Tribunal Federal quedó lejos del rol institucional diseñado por la nueva Constitución. El Alto Tribunal (y el Poder Judicial) no se convirtió en un participante activo en la lucha por la memoria ni en la punición a los responsables por los eventos violentos del pasado. Especialmente, en lo que se refiere a la dimensión del restablecimiento de la igualdad de los individuos frente a la ley. Por un lado, el Supremo Tribunal redujo su jurisdicción, lo que evitó la revisión legislativa preconstitucional (ADI no 2), por el otro al ser accionado, el Alto Tribunal convalidaba la ley de Amnistía y rechazaba su revisión (ADPF 153). El Supremo Tribunal demostró un activismo selectivo, de perfil conservador, en esta área en particular (Torelly, 2010b:276; Garrido da Silva y Ribas Vieira, 2009:258). De esta forma, contribuyó a las políticas de olvido e impunidad. Pero al no recurrir a él ${ }^{23}$, la ciudadanía demostró la falta de confianza en el STF y el Poder Judicial como canal de entrada para satisfacer sus demandas. Y la credibilidad de la justicia se gana por sus propias acciones, al garantizar un verdadero Estado de derecho (Lorenzetti, 2011:14). En palabras de Abrão: "... ao longo da lenta distensão do regime, (a lei de anistia) viria a ser convalidada, ainda, de forma expressa pelo Judiciário democrático e de forma tática pela própria militância política, que acabou, ao longo dos anos que seguiram a democratização, deixando de acionar o Ju- 
diciário para que este tomasse providências em relação aos crimes do passado" (2011:124). Ante esta situación, la dimensión de reparación se convirtió en el eje central en el que se basaron la mayor parte de las políticas de reconciliación brasileñas.

No obstante la ausencia institucional del Supremo Tribunal en la participación y punición, cinco eventos recientes revelaron importantes avances en la materia que, por un lado, muestran el fortalecimiento de la justicia transicional en Brasil, y por el otro, exponen las dificultades que aún permanecen en el camino. En primer lugar, en los últimos años, la justicia transicional pasó a ocupar un lugar destacado en la agenda política del Gobierno brasileño, lo que implica una notable diferencia respecto a los primeros años de la vuelta a la democracia. El 21 de diciembre de 2009, el presidente Lula da Silva aprobó el decreto no 7.037, que lanzaba el III Programa Nacional de Derechos Humanos de la Secretaria Especial de Derechos Humanos de la Presidencia de la República (SEDH). En este se eligió el Derecho a la Memoria y a la Verdad como uno de los principales ejes de orientación (Brasil 2010; MacDowell Santos, 2010:125). En segundo lugar, la condena dictada por la Corte Interamericana de Derechos Humanos sobre el Caso Gomes Lund y otros ("Guerrilha do Araguaia") a fines del 2010. Tercero, la decisión del Supremo Tribunal Federal sobre la revisión de la Ley de Amnistía, en la Arguição de Descumprimento de Preceito Fundamental no 153 en abril de $2010^{24}$. En cuarto lugar, a fines de 2011, la presidente Dilma Rousseff sancionó la creación de la Comisión de la Verdad. A pesar de las críticas, fue un paso más hacia la investigación de las violaciones de los derechos humanos y en la construcción de la memoria. En quinto, recientemente el Ministerio Público Federal tomó una postura activa y diferente, como en el caso Brilhante Ustra ${ }^{25}$, lo que abre nuevas oportunidades. En esta trayectoria, la presencia del STF fue tan conflictiva como su ausencia.

\section{EL SUPREMO TRIBUNAL FEDERAL: ENTRE LA JUSTICIA Y LA IMPUNIDAD}

Con el retorno a la democracia, Brasil debió enfrentar algunos de los principales dilemas de un Estado de derecho democrático: la reparación y punición a las violaciones de los derechos humanos ejecutadas por agentes del Estado durante el reciente régimen cívico-militar. En este sentido, Juan Méndez indica que al: “...reconocer que la reconstrucción postconflicto y la construcción de un verdadero Estado de derecho no pueden hacerse en base al olvido, a la ausencia de memoria y 
sobre la impunidad" (Mezarobba, 2007:177). El restablecimiento del Estado de derecho se presenta en general de forma combinada: por el establecimiento de garantías jurídicas mínimas para el futuro y, por la reparación y justicia con relación a las violaciones pasadas. La Constitución de 1988 reforzó de forma notable los mecanismos de defensa de derechos de los ciudadanos. Sin embargo, los intérpretes de la nueva Carta Magna provenían del antiguo régimen. En este sentido - es una particularidad del caso en análisis - los últimos cuatro miembros del STF nombrados en períodos no democráticos, se retiraron por límite constitucional de edad ya en el siglo $\mathrm{XXI}^{26}$. Al mismo tiempo, la presidencia del Supremo Tribunal fue presidida por miembros nombrados en períodos no democráticos hasta el año 1995. Estos eventos son relevantes tanto por la continuidad institucional como por la prolongada permanencia e influencia de ministros nombrados en períodos no democráticos. La composición del Alto Tribunal que provenía del régimen autoritario, en los primeros años de la vuelta a la democracia, fue la que estableció los límites para la revisión del pasado, determinando su propio rol institucional al mismo tiempo que alejaba su jurisdicción en el proceso de consolidación democrática en esta área en particular. En esta línea, lugar especial tiene el ADI no 2 de 1992 en el proceso de reducción de la jurisdicción del STF.

Este legado institucional autoritario mostró su fortaleza y vigencia al momento de juzgar las violaciones ocurridas en dictadura. Así, las medidas implementadas para lidiar con los eventos violentos del pasado se basaron en la reparación (no solamente económica ${ }^{27}$ ) y no en la punición de los responsables. Estas últimas se encontraron con las restricciones impuestas (y controladas) por el régimen autoritario saliente. En este sentido, como sugiere el presidente de la Comisión de Amnistía del Ministerio de Justicia del Brasil, Paulo Abrão:

(...) as medidas de abrangência temporal retroativa, como a investigação de crimes passados, enfrentaram de forma mais marcada as restrições políticas do antigo regime por atingirem diretamente a seus membros, enquanto as medidas de reparação às vítimas e garantia de direitos futuros se mostraram mais eficientes em romper o cerco político, na medida em que não afetavam de forma direta os membros do antigo status quo e as limitações que estes impuseram à transição quando ainda estavam no poder (2011:121).

Así, el STF rechazó las demandas contra las violaciones producidas en el régimen autoritario a partir de amplias interpretaciones de la Ley de 
Amnistía, especialmente la decisión ADPF 153. El legado institucional autoritario se materializó tanto en la presencia de interpretaciones conservadoras como en la ausencia de la participación en la búsqueda de la verdad y la justicia. La Ley de Amnistía prácticamente no fue cuestionada en los tribunales a lo largo de todos estos años democráti$\cos ^{28}$. La ADI no 2 fue influyente en este aspecto. Sin embargo, el cambio del milenio trajo consigo novedades y desafíos. Particularmente, dos eventos revelaron las disyuntivas (pasadas y futuras) con las que el STF lidiaría. Un evento tuvo lugar en el ámbito internacional y otro en el ámbito doméstico, pero ambos son parte del desafío contemporáneo brasileño.

En el ámbito nacional, en abril del 2008, la Orden de los Abogados de Brasil (OAB) interpuso una demanda ante el STF que cuestionaba la Ley de Amnistía, la conocida ADPF no 153. Específicamente, se exigió la interpretación del artículo n.1 de dicha ley. La OAB alegó ser notoria la controversia constitucional a propósito del ámbito de aplicación de la Ley de Amnistía. Éstos sustentaron que: "se trata de saber se houve ou não anistia dos agentes públicos responsáveis, entre outros crimes, pela prática de homicídio, desaparecimento forçado, abuso de autoridade, lesões corporais, estupro e atentado violento ao pudor contra opositores políticos ao regime militar" (Grau, 2010:2). Valiéndose de argumentos de carácter históricos, el ministro relator Eros Grau, alegó que no cabía al Poder Judicial rever el acuerdo político que resultó en la amnistía. En un sentido contrario fueron los ministros Ricardo Lewandowski y Ayres Britto, los dos únicos votos a favor de la revisión de la ley. Para ellos, ciertos crímenes son, por su naturaleza, absolutamente incompatibles con cualquier idea de criminalidad política pura o conexa. Con todo, en 2010, el pedido interpuesto por la OAB para revisar la Ley de Amnistía (no 6.683-1979) fue rechazado por el Supremo Tribunal por 7 votos contra 2. La decisión no fue bien recibida por todo el arco de organizaciones de derechos humanos tanto nacional como internacional. La decisión del STF fue en contraposición a la fuerte tendencia global de la responsabilidad penal individual de agentes públicos por violaciones a los derechos humanos (Sikkink, 2011:37). A pesar de ello, todavía se encuentran pendientes de decisión por parte del STF los embargo de declaración presentados por la OAB en agosto del 2010. Dicha presentación cuestiona el resultado de la decisión del STF sobre la ADPF 153, por lo que existe una eventual posibilidad de volver a discutir estos aspectos. 
En el ámbito internacional, en marzo del 2009, la Comisión Interamericana de Derechos Humanos presentó una demanda contra Brasil ante la Corte Interamericana de Derechos Humanos por el caso de la Guerrilla de Araguaia. Este proceso liderado por los familiares comenzó en 1982 en los tribunales brasileros, y agotó los recursos internos en 2001. En la Corte Interamericana, la Comisión solicitó que se determinase la responsabilidad internacional del Estado brasileño por el incumplimiento de una serie de obligaciones, entre ellas, la del derecho a la integridad personal y el derecho a la vida. La Comisión declaró que la presentación de la demanda ante la Corte Interamericana era: "uma oportunidade importante para consolidar a jurisprudência interamericana sobre as leis de anistia com relação aos desaparecimentos forçados e à execução extrajudicial e a consequente obrigação dos Estados de dar a conhecer a verdade à sociedade e investigar, processar e punir graves violações de direitos humanos". Además, sostuvo que era una posibilidad para: "o Tribunal afirmar a incompatibilidade da Lei de Anistia e das leis sobre sigilo de documentos com a Convenção Americana" (Corte IDH, 2010:3). El 14 de diciembre de 2010, la Corte publicó la sentencia y declaraba a Brasil responsable de la desaparición de 62 personas entre 1972 y 1974, en la región del río Araguaia. A diferencia de lo declarado por el STF, la Corte Interamericana concluyó: "que as disposições da Lei de Anistia que impedem a investigação e sanção de graves violações de direitos humanos são incompatíveis com a Convenção Americana e carecem de efeitos jurídicos, razão pela qual não podem continuar representando um obstáculo para a investigação dos fatos do caso, nem para a identificação e a punição dos responsáveis" (Corte IDH 2010:4).

A pesar que la Corte remarcó los avances en el ámbito de la reparación, determinó que el Estado no sólo debía revelar la verdad acerca de los crímenes, sino también investigar penalmente los hechos. Al mismo tiempo, la Corte responsabilizó al Estado brasileño por la violación al derecho de acceso a la información. La sentencia de la Corte Interamericana expuso de forma clara la incompatibilidad de la decisión del STF en la ADPF-153. De este modo, Brasil tiene que lidiar con las incompatibilidades y las obligaciones internacionales y evitar mayores inconvenientes en el ámbito internacional. En este sentido, es importante remarcar que el activismo legal transnacional, puede ayudar a cambiar el curso de una contienda legal pendiente en tribunales locales, a pesar de sus limitaciones (MacDowell Santos, 2007:52). Asimismo, en América Latina existen muchos procesos nacionales de respon- 
sabilización criminal individual. Varios de estos son instigados y fomentados tanto por instituciones regionales de derechos humanos como por ONG de derechos humanos nacionales e internacionales (Sikkink, 2011:71). En síntesis, estos son desafíos presentes en la realidad brasileña.

En el retorno a la democracia, la trayectoria y participación del Supremo Tribunal Federal en el proceso de búsqueda de la verdad y justicia lo ubica como curador destacado del legado autoritario nacional. El STF se coloca con este tipo de sentencia (ADPF-153) en posiciones opuestas al liderazgo e innovación judicial a nivel internacional, como es el caso de la Corte Suprema de Justicia Argentina en el ámbito de derechos humanos (Sikkink, 2008: 23). La comparación con la Corte Suprema Argentina es importante para observar otro tipo de participación institucional en el proceso de búsqueda de la verdad y justicia ${ }^{29}$. Especialmente, por haber sido el único país que anuló legalmente las leyes de amnistía. De forma breve, en el 2001, el Centro de Estudios Legales y Sociales (CELS) presentó el caso Simón y un juez Federal declaró la nulidad de las leyes de Punto Final (1986) y Obediencia Debida (1987) Leyes de Amnistía - por ser incompatibles con las obligaciones internacionales del Estado ${ }^{30}$. La decisión del Caso Simón fue confirmada por la Cámara Federal de Apelación de Buenos Aires. En agosto de 2003, con Néstor Kirchner en la presidencia, el Congreso dictó la Ley no 25.779 que declaró la nulidad de aquellas leyes (Punto Final y Obediencia Debida), dejándolas sin efecto. En julio del 2005, la Corte Suprema confirmó la decisión del caso Simón y convalidó la Ley no 25.779. Además, declaró que el crimen de desaparición forzada es un crimen contra la humanidad, que ninguna limitación le es aplicable. En 2006, un tribunal declaró inconstitucional la Ley de Indultos (a los miembros de la Junta Militar condenados en 1985) y en el 2007 esta decisión fue confirmada por la Corte Suprema Argentina. En definitiva, en el caso argentino, existe una revisión de las leyes de amnistía por parte del Alto Tribunal. Además, al igual que en el caso brasileño, existieron declaraciones de la CIDH sobre la incompatibilidad de este tipo de leyes con la Convención Interamericana de Derechos Humanos. A diferencia del Supremo Tribunal Federal, existe en la trayectoria argentina una participación activa de la Corte Suprema y los tribunales inferiores. Al mismo tiempo, la tarea de la sociedad civil y movimientos sociales fue un pilar fundamental para este proceso de búsqueda de la verdad y justicia. 


\section{CONSIDERACIONES FINALES}

Con el golpe de estado de 1964, el nuevo régimen cívico-militar instauró una dictadura con ropaje democrático y legal. Las instituciones fueron alteradas a partir de Actos Institucionales, complementarios, enmiendas constitucionales y nuevas cartas fundamentales. El régimen se atribuyó "o exercício de Poder Constituinte, inerente a todas as revoluções".

Existen tres momentos identificables en este régimen autoritario de 21 años de extensión: el golpe, la clausura y el proceso de apertura. En cada una de estas fases existieron realineaciones en la coalición dominante. Y estas generaron consecuencias en la dinámica política e institucional del Brasil. Desde el golpe hasta el AI no 5, la construcción de un Estado autoritario fue gradual y desordenada. A partir del AI no 5, la reconfiguración política en la coalición dejó la línea dura en el poder y con ella se materializó el fortalecimiento de medidas autoritarias. Finalmente, el proceso de apertura sacudió constantemente a la interna militar. En este proceso, el realineamiento político interno de la coalición fue constante y fue determinando el tipo de apertura que se iba presentando lentamente. La prolongada transición, negociada entre los diversos sectores y controlada por los militares, desembocó en la vuelta a la democracia en 1985. Como se expuso, los actores tratan de interpretar o reorientar las instituciones para alcanzar ventajas para el logro de sus objetivos o intereses. Observar los cambios en las coaliciones es importante porque las instituciones se apoyan en ellas (Thelen, 2004:31-33). En este sentido, el Supremo Tribunal Federal fue una institución constantemente observada, fue redirigida y moldeada de manera gradual hacia las nuevas necesidades de la coalición dominante en el poder.

La trayectoria del STF puede ser divida en dos momentos bien claros, antes del AI no 5 e no 6, y después de aquellos. En el primer período, de forma paulatina la arquitectura institucional brasileña comenzó a erosionarse. Sin embargo, el Alto Tribunal continuó trabajando en un ámbito conflictivo aunque con algunas capacidades básicas. En el segundo momento, la arquitectura jurídica cívico-militar se armonizó y consolidó definitivamente el autoritarismo centralizado. Aquí, el STF adquirió un rol institucional menor, de poca estatura, extinguiéndose las capacidades básicas de un poder del Estado. La imposibilidad de controlar los actos del Gobierno es, sin duda, importante para la compren- 
sión del papel desempeñado por el Alto Tribunal. Existen en el desarrollo de esta fase reformulaciones en las capacidades, pero ninguna de ellas le devolvió su verdadero rol institucional.

Como fue expuesto en el transcurso del trabajo, en el análisis histórico del Supremo Tribunal Federal se observan dos tipos de alteraciones institucionales que lo afectaron profundamente: las alteraciones en la estructura y en las capacidades. En el caso brasileño, el golpe de Estado significó un quiebre con consecuencias institucionales en la arquitectura de Brasil. Por una parte, con relación a la estructura, el tamaño del Alto Tribunal pasó de 11 a 16 ministros en los inicios del régimen autoritario y, posteriormente, volvió a 11 miembros. Además, existieron 3 alejamientos forzados de ministros de peso. Después de cinco años del golpe militar, los ministros del Supremo Tribunal Federal fueron sustituidos casi en su totalidad (solamente el juez Gallotti continuó). Por otra parte, los cambios producidos en las capacidades fueron extensos y cada uno tuvo diferentes grados de importancia en las consecuencias institucionales. La dinámica de las transformaciones graduales y constantes de las capacidades del Alto Tribunal fue contundente durante todo el período estudiado y, pronto, sería decisiva para reducir el rol institucional del STF en el escenario político brasileño. Estas transformaciones fueron, además, la principal estrategia del gobierno militar para cambiar gradualmente el rumbo de acción del Alto Tribunal. Alteraciones que se realizaron a partir de una legislación unilateral producida por el Ejecutivo de turno. A pesar de intentar implementar una legislación con pretensión de legalidad democrática, ésta estaba construida a partir de la informalidad autoritaria.

De forma complementaria a las intervenciones sobre las capacidades, el régimen cívico-militar fue erosionando la estructura del Alto Tribunal hasta conseguir una renovación acorde a los nuevos fines revolucionarios. Los medios y las formas utilizadas para alterar la estructura del Supremo Tribunal siempre fueron informales. De este modo, al modificar las capacidades y la estructura del Alto Tribunal, el régimen logró el reajuste institucional acorde a los nuevos objetivos y la garantía del tipo de funcionamiento. Un proceso de ajuste institucional para adaptarla a nuevos objetivos (Thelen, 2004:34-35). A partir de estas transformaciones graduales y constantes, el régimen autoritario fue reduciendo tanto el rol institucional del Supremo Tribunal Federal como su importancia política en un contexto de autoritarismo, violencia y necesidad. 
Con el cambio de régimen y la redemocratización, el Supremo Tribunal fue nuevamente afectado. Pero las alteraciones producidas fueron solamente en las capacidades. Es decir, con la Constitución de 1988, las capacidades del Alto Tribunal fueron restituidas y aumentadas. Y estas modificaciones ubicaron al STF en una posición de privilegio en la reconstrucción del orden constitucional brasileño. Sin embargo, la estructura del Alto Tribunal no se alteró: no se aumentó el tamaño del tribunal ni se modificó su composición. No existió un cambio profundo con relación al pasado, privilegiándose la continuidad institucional y los legados autoritarios. Fue en los primeros años que esta estructura, que provenía del antiguo régimen, estableció, a través de la jurisprudencia, los límites institucionales a la revisión del pasado autoritario. En 1992, el Supremo Tribunal Federal a través de la ADI no 02, apartó su jurisdicción de cuestiones relativas a conflictos con legislación preconstitucional y generó una continuidad institucional. En 2010, la ADPF 153 ratificó la vigencia de la Ley de Amnistía y convalidando esta ley en la democracia. De forma armónica y selectiva, convalidó el pasado en el futuro y prohibió al futuro rever el pasado. De ahí, la importancia de la restructuración de las instituciones. Reformar las instituciones públicas, particularmente las judiciales, es una tarea central de las sociedades postconflicto (Morales, 2011:81; Ndulo et al., 2009:253). La continuidad de la estructura proveniente del régimen militar convirtió al Supremo Tribunal Federal en un refugio del legado institucional autoritario. Y este legado afectó tanto el rol institucional del Supremo Tribunal como perjudicó el juicio y la punición a los responsables por los eventos violentos en la última dictadura.

Es exactamente en el ámbito del juicio y punición a los responsables que la justicia transicional encontró los mayores obstáculos y dilemas. Como señalan Abrão y Torelly (2011:226): “Quanto à dimensão da regularização da justiça e restabelecimento da igualdade perante a lei, que se constitui na obrigação de investigar, processar e punir os crimes do regime têm-se atualmente os maiores obstáculos". Pero la timidez institucional, en esta área en particular que demostró el Alto Tribunal no se reprodujo al defender la imposibilidad de revisión de la Ley de Amnistía (ADPF, 153). Un claro activismo selectivo, de perfil conservador (Torelly, 2010a; Garrido da Silva y Ribas Vieira, 2009). A través de la jurisprudencia, sostiene la continuidad directa y objetiva entre el sistema jurídico de la dictadura y el de la democracia. Y con ellas, los obstáculos jurídicos restringieron aún más la posibilidad de obtener una responsabilización penal por las violaciones producidas (Abrão y To- 
relly, 2011:242). De manera categórica, en palabras de Koerner et al.: “O veto de setores militares e seus aliados civis a propostas de adoção de políticas estatais para a reconstrução da verdade, da responsabilidade e da reparação, aliado ao imobilismo da maioria das lideranças políticas do país diante desse contexto, significam que o Estado democrático de direito organizado pela Constituição de 1988 ainda não foi instituído socialmente no Brasil" (2009:197).

Sin embargo, en el desarrollo de la justicia transicional, la condena de la Corte Interamericana de Derechos Humanos en el Caso Araguaia exhibió las incompatibilidades respecto a las obligaciones internacionales en el ámbito de los derechos humanos. La sentencia abrió nuevas posibilidades para exigir nuevas manifestaciones del Supremo Tribunal Federal. Y con ella, los límites, jurisprudenciales y políticos, están siendo desafiados. La novedosa postura del Ministerio Público Federal en el caso Brilhante Ustra, abre nuevas oportunidades. Además, los embargos de declaración de la ADPF 153 presentados por la OAB deberán ser juzgados en un horizonte cercano. La presentación del Informe final (con conclusiones y recomendaciones) por parte de la Comisión de la Verdad se convertirá en un nuevo paso en la justicia transicional. Y existe en Brasil un fortalecimiento de las entidades de derechos humanos, motor principal de la justicia transicional. Estos movimientos, entre otros, presionan y / o exigen al Supremo Tribunal Federal nuevas manifestaciones sobre las violaciones del pasado reciente. El desarrollo y fortalecimiento en las diversas dimensiones de la justicia transicional pueden provocar los cambios pendientes en el Poder Judicial, en general, y en el Supremo Tribunal Federal, en particular.

(Recebido para publicação em janeiro de 2013) (Reapresentado em agosto de 2013) (Aprovado para publicação em março de 2014) 


\section{NOTAS}

1. Palabras finales de su voto en la sentencia sobre la revisión de la Ley de Amnistía (ADPF-153, abril 2010).

2. Corte IDH, Sentencia del Caso Gomes Lund (Guerrilla de Araguaia) y otros c. Brasil, 14 de diciembre de 2010.

3. Como indicó la Corte IDH: "las actividades e informaciones que, eventualmente, recoja (la comisión de la verdad), no sustituirán la obligación del Estado de establecer la verdad y asegurar la determinación judicial de responsabilidades individuales, a través de procesos penales" (Corte IDH. Caso Gomes Lund y otros c. Brasil - sentencia del 24/11/2010). Además, es parte de la labor de la Comisión observar la responsabilidad del Poder Judicial por su omisión o connivencia en el caso de que esta exista.

4. En este escenario político, fueron destituidos 49 jueces (Fausto, 2002:467).

5. El 15 de abril de 1964, tomó pose como presidente Castelo Branco. Su mandato fue prorrogado hasta el 15 de marzo de 1967, a través de la Enmienda Constitucional no 9 del 22 de julio de 1964.

6. Ver entrevistas a los ministros de la época por Vale (1976:180).

7. Fueron determinantes los habeas corpus concedidos al gobernador del Estado de Goiás, Borges Teixeira, y al exgobernador del Estado de Amazonas, Plínio Coelho.

8. De formas sucinta, el AI no 2 instauró la elección indirecta para la presidencia de la República, disolvió todos los partidos políticos y se permitió crear otros, estableció la facultad presidencial de declarar el Estado de sitio por 180 días sin consulta al legislativo, se podría intervenir en los estados, decretar el receso del Congreso, destituir funcionarios por incompatibilidades con el régimen y dictar decretos ley sobre cuestiones de seguridad nacional. Además, se reservó al presidente el derecho de enviar al Congreso los proyectos de enmienda constitucional, los que debían ser apreciados en 30 días y aprobados con mayoría de las dos casas legislativas.

9. En esta fase se realizaron algunas expurgaciones en el Poder Judicial (Pereira, 2010:91).

10. Con relación a las garantías de los jueces, la nueva Constitución estableció en su artículo 108: "Salvo as restrições expressas nesta Constituição, gozarão os Juízes das garantias seguintes: III - irredutibilidade de vencimentos, sujeitos, entretanto, aos impostos gerais $\S 1^{\mathrm{o}}$ - A aposentadoria será compulsória aos setenta anos de idade ou por invalidez comprovada, e facultativa após trinta anos de serviço público, em todos esses casos com os vencimentos integrais".

11. Declaración emitida el último día de 1968.

12. Costa e Silva se alejó del ejecutivo por cuestiones de salud. El 31 de agosto de 1969 se decretó la AInํ12 que estableció que mientras dure la imposibilidad física de Costa e Silva, la junta militar administraba el país. El 14 de octubre, el AI no 16 declaró vagos el cargo de presidente (y vice), convocándose a elecciones por el Congreso el 25 de octubre.

13. Con relación a las garantías de los jueces, en su artículo 113 se estableció: "Salvo as restrições expressas nesta Constituição, os juízes gozarão das seguintes garantias: III - irredutibilidade de vencimentos, sujeitos, entretanto, aos impostos gerais, inclusi- 
ve o de renda, e os impostos extraordinários previstos no artigo 22". Sin embargo, el artículo sobre la edad de retiro fue extinguido, creando un vacío funcional a las necesidades del régimen.

14. La enmienda creó la representación para la interpretación de la ley o de acto normativo federal o estadual (art. 119, I, l de la Constitución Federal), con lo que se completó el control de constitucionalidad, de forma que atienda al predominio absoluto de la Constitución (Dias Corrêa, 1987:24).

15. Un factor relevante para la comprensión de los cambios en el concepto de amnistía se presentó con la convocatoria de la Asamblea Constituyente, a través de una enmienda constitucional. Esta enmienda reafirmó la amnistía bajo la ley de 1979, incluidas sus ambigüedades. La reafirmación de la amnistía ambigua, "bilateral" en contexto de la enmienda tuvo la intención de "constitucionalizar" dicho dispositivo y reiterar el tamaño de la amnistía como "la impunidad y olvido" (Abrão e Torelly, 2012:24).

16. Con la revolución de 1930 y con el Estado Novo en 1937, Vargas apartó a ministros.

17. La Federação Nacional de Estabelecimentos de Ensino presentó una ADI al STF contra la

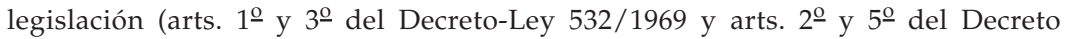
95.921/1988).

18. Agradezco el debate sobre el tema y los comentarios del profesor Diego Werneck Arguelhes, entre muchos otros.

19. La primera decisión del STF sobre una ADPF fue en 2005.

20. Dado el sistema partidario brasileño, presidencialismo de coalición, la selección de los ministros es más negociada y consensuada. Los miembros nombrados no son fieles sostenedores del presidente de turno. La alta negociación partidaria, ex-ante, hace que Brasil tenga una tasa de aprobación del 97\% de los candidatos propuestos (del Río, 2011).

21. Se considera que la medida provisoria $65 / 2002$, que reglamento el artículo 8 , fue dictada por el expresidente Fernando Henrique Cardoso, fue aprobada por el Congreso Nacional y convertida en ley finalmente el 13 de noviembre de 2002. Fue durante el gobierno de Lula da Silva que la Comisión de Amnistía ganó legitimidad.

22. La comisión fue orientada a reparar actos de excepción, incluyendo torturas y prisiones arbitrarias, entre otros.

23. Fueron excepcionales los casos que llegaron al Supremo Tribunal con relación a la ley de amnistía en el periodo 1988 a 2010. En general, los casos trataron cuestiones relacionadas a la reparación y reajustes monetarios.

24. Tanto la condena de la Corte IDH como la decisión ADPF 153 serán tratadas en la próxima sección.

25. El 29 de abril de 2013, el Ministério Público Federal (MPF), en São Paulo, denunció por el delito de ocultamiento de cadáver de Hirohaki Torigoe, al Coronel retirado Carlos Alberto Ustra Brillante, comandante del Destacamento de Operaciones de Información - Centro de Operaciones de Defensa interna de São Paulo (DOI-Codi) en el período de 1970 y 1974. Pero no fue la única denuncia. El 23 de octubre de 2012, el MPF denunció al Coronel retirado de secuestrar y torturar a Edgar Duarte Aquino, en junio de 1971. Se agrega que el Tribunal de Justicia de São Paulo (TJ-SP) reconoció como torturador al Coronel durante el régimen militar (1964-1985). La decisión no tiene precedentes en Brasil, ya que es la primera vez que un tribunal superior reconoce 
la responsabilidad de un agente del Estado acusado de violar los derechos humanos. La sentencia fue emitida el 8 de octubre de 2008, en 23ํㅡ Juzgado en lo Civil del Foro John Mendes.

26. Tres miembros nombrados por João Figueiredo y uno nombrado por Ernesto Geisel se retiraron como ministros del STF en el 2000, 2002 y, en dos casos en el 2003.

27. Medidas como la declaración del amnistiado político, la garantía del retorno al curso en escuela pública, el registro de diplomas universitarios obtenidos en el exterior, la localización de los restos mortales de los desaparecidos, entre otras medidas de carácter no económico.

28. Son marginales los casos relacionados con la Ley de Amnistía que llegaron al STF. De una simple investigación en la jurisprudencia del Alto Tribunal a partir del término “Ley Amnistía” y “Ley Amnistía 6.683": 27 acordões (fallos judiciales) fueron el resultado, de los cuales el ADPF 153 es de 2010, los otros son del período 1979 a 1986. En general, la temática de esos acordões apuntan a cuestiones relativas a la reparación económica (inclusión, reajuste, jubilación, pensión etc.). Existen 5 decisiones "monocráticas": una petición por cuestiones de reparación de 2004, una medida cautelar por habeas corpus por el caso de un individuo de nacionalidad argentina de 2008, un recurso extraordinario para revisar el cálculo de una jubilación de un amnistiado de 2009, un recurso de amparo por el valor de la pensión de 2009 y un agravio de instrumento por recurso de corrección monetaria del amnistiado del 2010. El tema amnistía no aparece como jurisprudencia seleccionada en la STF en línea, pero si es considerado como caso notorio por la ADPF.153. Otros casos que son de interés a la justicia transicional y llevaron al debate sobre la ley de amnistía de alguna forma: la ADI 4.077 de sigilo de documentos públicos y la ADI 3.987 de acceso a la información. También es importante la extradición no 974, que involucró el tema Operación Cóndor.

29. Según Piovesan (2011:80), existen tres factores en ambos casos (Brasil y Argentina) que hacen interesante la comparación: a) Ambos países transitaron de regímenes dictatoriales para regímenes democráticos, adoptando leyes de Amnistía - en Argentina, las leyes de Punto Final (Ley no 23.492/1986) y Obediencia Debida (Ley no 23.521/1987); en el caso brasileiro, la Ley no $6.683 / 1979$; b) ambos adoptaron un nuevo marco normativo (la reforma constitucional de 1994, en Argentina, y la nueva Constitución de 1988, en Brasil); c) ambos le dan a los tratados de derechos humanos un status privilegiado en su orden jurídica (artículo 75, inc. 22 de la Constitución Nacional Argentina y el artículo 5, inc. 2 y 3 de la Constitución Brasileña).

30. La Comisión de Derechos Humanos ya había declarado en un informe en 1992 que las leyes de impunidad y los indultos presidenciales de Menem violaban la Convención Americana de D.H. (Filippini, 2011:24-26). En el 2002, la Corte IDH reafirmó tal posición al declarar en el Caso Barrios Altos que dos leyes de amnistía peruanas eran inválidas e incompatibles con la Convención Americana de D.H. (Sikkink, 2008:12). 


\section{Dictadura, Democracia y Justicia Transicional en Brasil...}

\section{BIBLIOGRAFÍA}

ABRÃO, Paulo. (2011), “A Lei de Anistia no Brasil. As Alternativas para a Verdade e a Justiça". Acervo, vol. 24, no 1, pp. 119-138.

- y TORELLY, Marcelo D. (2011), “As Dimensões da Justiça de Transição no Brasil, a Eficácia da Lei de Anistia e as Alternativas para a Verdade e a Justiça”, en A Anistia na Era da Responsabilização: O Brasil em Perspectiva Internacional e Comparada. Brasília, Ministério da Justiça, Comissão de Anistia; Oxford, Oxford University Press, Latin American Centre.

. (2012), “Mutações do Conceito de Anistia na Justiça de Transição Brasileira: A Terceira Fase da Luta pela Anistia". Revista Anistia Política e Justiça de Transição, no 7, pp. 10-47.

ANDRADE, Luciana Sater de. (2009), “Controle de Constitucionalidade das Normas Pré-Constitucionais na Jurisprudência do STF: O Julgamento da ADI 02, as Razões Determinantes do Tribunal e as Consequências da Postura Adotada", in D. Coutinho e A. M. Vojvodic (orgs.), Jurisprudência Constitucional: Como Decide o STF?. São Paulo, Editora Malheiros/Sociedade Brasileira de Direito Público.

BARROSO, Luiz Roberto. (2009), Direito Constitucional Contemporâneo. Os Conceitos Fundamentais e a Construção do Novo Modelo. São Paulo, Saraiva.

BRASIL. Secretaria Especial dos Direitos Humanos. Comissão Especial sobre Mortos e Desaparecidos Políticos. (2007), Direito à Verdade e à Memória: Comissão Especial sobre Mortos e Desaparecidos Políticos. Brasília, Secretaria Especial dos Direitos Humanos.

BRASIL. Secretaria Especial dos Direitos Humanos da Presidência da República. (2010), Programa Nacional de Direitos Humanos (PNDH3). Brasília, Secretaria Especial dos Direitos Humanos da Presidência da República.

CORTE INTERAMERICANA DE DERECHOS HUMANOS. (2010), Caso Gomes Lund y Otros - Guerrilla de Araguaia - c. Brasil - sentencia del 24 de Noviembre de 2010.

DEL RÍO, Andrés. (2010), El Desarrollo Institucional de la Corte Suprema de Justicia Nacional y del Supremo Tribunal Federal. Trayectorias Comparadas desde el Establecimiento a la Redemocratización. Tesis de Doctorado, IESP-UERJ, Rio de Janeiro.

. (2011), "A Relação ente Corte Suprema e o Poder Executivo na Argentina e no Brasil: Um Olhar Histórico Institucional”, in R. Boschi (org.), Variedades de Capitalismo, Política e Desenvolvimento na América Latina. Belo Horizonte, UFMG Editora.

DIAS CORRÊA, Oscar. (1987), O Supremo Tribunal Federal, Corte Constitucional do Brasil. Rio de Janeiro, Forense.

FAUSTO, Boris. (2002), Historia do Brasil. São Paulo, EdUSP.

FILIPPINI, Leonardo. (2011), “La Persecución Penal en la Búsqueda de Justicia”, in Centro de Estudios Legales y Sociales (CELS), Hacer Justicia: Nuevos Debates sobre el Juzgamiento de Crímenes de Lesa Humanidad en la Argentina. Buenos Aires, Siglo Veintiuno.

GARRIDO DASILVA, Alexandre e RIBAS VIEIRA, José. (2009), “Justiça Transicional, Direitos Humanos e a Seletividade do Ativismo Judicial no Brasil". Revista Anistia Política e Justiça de Transição, no 2. 


\section{Andrés del Río}

GASPARI, Elio. (2002a), A Ditadura Envergonhada. São Paulo, Companhia das Letras, vol. 1, Coleção O Sacerdote e o Feiticeiro.

. (2002b) A Ditadura Escancarada. São Paulo, Companhia das Letras, vol. 2, Coleção As Ilusões Armadas

GENRO, Tarso y ABRÃO Paulo. (2010), “Memória Histórica, Justiça de Transição e Democracia sem Fim", in B. de S. Santos et al. (orgs.), Repressão e Memória Política no Contexto Ibero-Brasileiro: Estudos sobre Brasil, Guatemala, Moçambique, Peru e Portugal. Brasília, Ministério da Justiça, Comissão de Anistia; Portugal, Universidade de Coimbra, Centro de Estudos Sociais.

GRAU, Eros Roberto. (2010), ADPF 153, Voto do Ministro Relator. Brasília, Supremo Tribunal Federal.

KOERNER, Andrei. (2010), Representação e Justiça: Uma Hipótese sobre o Judiciário no Brasil pós-1930. Trabalho apresentado no 7o Encontro da Associação Brasileira de Ciência Política. Recife, 4-7 de agosto.

e ASSUMPÇÃO, San Romanelli. (2009), “A Lei de Anistia e o Estado Democrático de Direito no Brasil”. Revista Brasileira de Ciências Sociais, vol. 24, no69, pp. 194-197.

LORENZETTI, Ricardo Luis y KRAUT, Alfredo Jorge. (2011), Derechos Humanos: Justicia y Reparación. Buenos Aires: Sudamericana.

MACDOWELL SANTOS, Cecília. (2007), “El Activismo Legal Transnacional y el Estado: Reflexiones sobre los Casos contra Brasil en el Marco de la Comisión Interamericana de Derechos Humanos. SUR - Revista Internacional de Direitos Humanos, año 4, no 7, pp. 29-59.

. (2010), “Questões de Justiça de Transição: A Mobilização dos Direitos Humanos e a Memória da Ditadura no Brasil", in B. de S. Santos et. (orgs.), Repressão e Memória Política no Contexto Ibero-Brasileiro: Estudos sobre Brasil, Guatemala, Moçambique, Peru e Portugal. Brasília, Ministério da Justiça, Comissão de Anistia; Portugal, Universidade de Coimbra, Centro de Estudos Sociais.

MEZAROBBA, Glenda. (2004), “Entre Reparaciones, Medias Verdades e Impunidad: La Difícil Ruptura con el Legado de la Dictadura en Brasil". SUR - Revista Internacional de Derechos Humanos, vol. 7, no 13, pp. 7-26.

(2007), Entrevista con Juan Méndez, presidente del International Center for Transitional Justice (ICTJ). SUR - Revista Internacional de Derechos Humanos, vol. 4, no 7, pp. 168-175.

MORALES, Diego R. (2011), “Limitaciones al Acceso a Cargos Públicos para Implicados en Crímenes de Lesa Humanidad", in Centro de Estudios Legales y Sociales (CELS), Hacer Justicia: Nuevos Debates sobre el Juzgamiento de Crímenes de Lesa Humanidad en la Argentina. Buenos Aires, Siglo Veintiuno.

NDULO, Muna B. y DUTHIE, Roger. (2009), “The Role of Judicial Reform in Development and Transitional Justice", en P. Greiff y R. Duthie (orgs.), Transitional Justice and Development. Making Connections. International Center for Transitional Justice, Advancing Transitional Justice Series. New York, Social Science Research Council. 
OLSEN Tricia, PAYNE Leigh y REITER Andrew. (2009), “Equilibrando Julgamentos e Anistias na América Latina: Perspectivas Comparativa e Teórica". Revista Anistia Política e Justiça de Transição, vol. 1, no 2, pp. 152-175.

PEREIRA, Anthony W. (2010), Ditadura e Repressão: O Autoritarismo e o Estado de Direito no Brasil, no Chile e na Argentina. São Paulo, Paz e Terra.

PIERSON, Paul. (2008), "Big, Slow - Moving, and... Invisible. Macrosocial Processes in the Study of comparative Politics", en J. Mahoney y D. Rueschemeyer (eds.), Comparative Historical Analisys in the Social Science. Cambridge, Cambridge University Press.

PIOVESAN, Flavia. (2011), "Lei de Anistia, Sistema Interamericano e o Caso Brasileiro", en L. F. Gomes y V. O. Mazzuoli (orgs.), Crimes da Ditadura Militar: Uma Análise à Luz da Jurisprudência Atual da Corte Interamericana de Direitos Humanos: Argentina, Brasil, Chile, Uruguai. São Paulo, Editora Revista dos Tribunais.

RIBEIRO BASTOS, Celso. (1999), Curso de Direito constitucional. São Paulo, Saraiva.

SIKKINK, Kathryn. (2011), “A Era da Responsabilização: A Ascensão da Responsabilização Penal Individual", en A Anistia na Era da Responsabilização: O Brasil em Perspectiva Internacional e Comparada. Brasília, Ministério da Justiça, Comissão de Anistia; Oxford, Oxford University Press, Latin American Centre.

SIKKINK, Kathryn. (2008), “From Pariah State to Global Protagonist: Argentina and the Struggle for International Human". Latin American Politics and Society, vol. 50, no 1, pp. 1-29.

SOARES, Gláucio Ary Dillon y D'ARAUJO, Maria Celina (orgs.). (1994), 21 Anos de Regime Militar: Balanços e Perspectivas. Rio de Janeiro, FGV Editora.

STREECK, Wolfgang y THELEN, Kathleen (eds.). (2005), Beyond Continuity. Institutional Change in Advanced Political Economies. Oxford/New York, Oxford University Press.

THELEN, Kathleen. (2004), How Institutions Evolve. The Political Economy of Skills in Germany, Britain, the United States and Japan. Cambridge, Cambridge University Press.

TORELLY, Marcelo D. (2010a), "Justiça Transicional, Memória Social e Senso Comum Democrático: Notas Conceituais e Contextualização do Caso Brasileiro", en B. de S. Santos et al. (orgs.), Repressão e Memória Política no Contexto Ibero-Brasileiro: Estudos sobre Brasil, Guatemala, Moçambique, Peru e Portugal. Brasília, Ministério da Justiça, Comissão de Anistia; Portugal: Universidade de Coimbra, Centro de Estudos Sociais.

(2010b), Justiça Transicional e Estado Constitucional de Direito: Perspectiva Teórico-Comparativa e Análise do Caso Brasileiro. Dissertação de Mestrado em Direito, Estado e Constituição, Universidade de Brasília, Faculdade de Direito, Brasília.

VALE, Osvaldo Trigueiro do. (1976), O Supremo Tribunal Federal e a Instabilidade Politico-institucional. Rio de Janeiro, Civilização Brasileira.

VILHENA VIEIRA, Oscar. (1994), Supremo Tribunal Federal: Jurisprudência Política. São Paulo, Editora Revista dos Tribunais. 


\section{RESUMO}

Ditadura, Democracia e Justiça Transicional no Brasil: Trajetória e Legados do Supremo Tribunal Federal

O objeto principal deste artigo é contribuir com o debate contemporâneo sobre justiça de transição, observando a participação do Supremo Tribunal Federal do Brasil neste processo. Para tal fim, analisa-se a trajetória e as mudanças institucionais do Supremo Tribunal Federal durante o regime civil-militar instaurado em 1964. De forma mais específica, examinam-se os meios e os objetos das mudanças institucionais, o cenário político e as continuidades e legados do Alto Tribunal na democracia, com foco especial nas violações aos direitos humanos produzidas pelos agentes estatais durante o regime autoritário. O texto finaliza com uma análise comparativa do tipo de mudança institucional ocorrida tanto na ditadura como na democracia.

Palavras-chave: mudanças institucionais; regime militar; Supremo Tribunal Federal; justiça transicional; Brasil

\section{ABSTRACT \\ Dictatorship, Democracy and Transitional Justice in Brazil: Trajectory and Legacies of the Federal Supreme Court}

The main goal of this article is to contribute to the current debate on transitional justice, observing the participation of the Brazilian Supreme Court (Supremo Tribunal Federal) in this process. To this end, the trajectories and institutional transformations of the Supreme Court during the last period of civil-military rule initiated in 1964 are analyzed. In particular, the article investigates the means and goals of institutional changes, the political context and points out the continuation and legacies of the High Court in democracy, paying special attention to the violation of human rights carried out by state actors during the authoritarian regime. It concludes with a comparative analysis of the type of institutional transformation which occurred both during the authoritarian period as well as in democratic times.

Keywords: institutional transformations; military regime; Federal Supreme Court; transitional justice; Brazil 


\section{RÉSUMÉ}

Dictature, Démocratie et Justice Transitoire au Brésil: Trajectoire et Héritage de la Cour Suprême Fédérale

L'objectif principal de cet article est de contribuer au débat en cours sur la justice transitionnelle, a partir de l'observation de la participation de la Cour Suprême Fédérale (Supremo Tribunal Federal) du Brésil dans ce processus. Pour atteindre cet objectif, sont analysés les trajectoires et les changements institutionnels de la Cour suprême au cours du dernier régime civique-militaire en 1964. En particulier, sont observés les moyens et les objets des changements institutionnels, la scène politique et les continuités et legs de la Cour Suprême dans la démocratie, avec une attention spéciale aux violations des droits humains imputables aux agents de l'État sous le régime autoritaire. L'étude finit avec une analyse comparative du type de changement institutionnel qui a existé à la fois durant la dictature et la démocratie.

Mots-clés: changements organisationnels; régime militaire; Cour Suprême Fédérale; justice transitionnelle; Brésil

\section{RESUMEN}

Dictadura, Democracia y Justicia Transicional en Brasil: Trayectoria y Legados del Supremo Tribunal Federal

El objetivo principal de este artículo es contribuir al debate actual sobre justicia transicional, observando la participación del Supremo Tribunal Federal de Brasil en este proceso. Para ello, se analiza la trayectoria y los cambios institucionales del Supremo Tribunal durante el último régimen cívico-militar instaurado en 1964. Particularmente, se observan los medios y los objetos de los cambios institucionales, el escenario político y las continuidades y los legados del Alto Tribunal en la democracia, con especial atención para las violaciones a los derechos humanos producidas por los agentes estatales durante el régimen autoritario. El estudio concluye con un análisis comparativo del tipo de cambio institucional que existió tanto en dictadura como en democracia.

Palabras clave: cambios institucionales; régimen Militar; Supremo Tribunal Federal; justicia transicional; Brasil 